\title{
ФОРМУВАННЯ У СТУДЕНТІВ ПРИРОДНИЧИХ СПЕЦІАЛЬНОСТЕЙ ПЕДАГОГІЧНИХ ЗАКЛАДІВ ВИЩОЇ ОСВІТИ ЦІЛІСНОГО УЯВЛЕННЯ ПРО ПРИРОДУ
}

\author{
Колесник Марина Олександрівна \\ к. пед. н., Національний університет «Чернігівський колегіум» імені Т.Г. Шевченка, \\ Чернігів, Украӥна \\ ORCID ID: http://orcid.org/0000-0003-0775-4035
}

DOI: https://doi.org/10.31435/rsglobal_ijitss/31052020/7059

\section{ARTICLE INFO}

Received 20 March 2020

Accepted 15 May 2020

Published 31 May 2020

\section{KEYWORDS}

interdisciplinary approach, universal scientific worldview, world outlook.

ABSTRACT

The article tackles the issue of construing the educational content from the standpoint of interdisciplinary causative-systemic approach and previously introduced pattern of shaping pedagogical universities' students' universal scientific worldview (USW). The paper discusses theoretical premises of forming future natural sciences' teachers' integral image of Nature. The suggested approach advocates the integration of data from diverse fields of science in the process of modeling educational content, discusses the notion of the "image of the world" and allocates it in the structure of naturalscientific education. Construing respective academic courses' content encompasses the focal idea of natural causality. The article presents the results of the suggested USW model's analysis and dwells on the results of implementing an experimental course into a curriculum. The paper highlights the said model's axiological potential.
\end{abstract}

Citation: Kolesnyk M. O. (2020) Shaping Natural-Sciences Majoring Pedagogical University Students' Integral Concept of Nature. International Journal of Innovative Technologies in Social Science. 4(25). doi: 10.31435/rsglobal_ijitss/31052020/7059

Copyright: (C) 2020 Kolesnyk M. O. This is an open-access article distributed under the terms of the Creative Commons Attribution License (CC BY). The use, distribution or reproduction in other forums is permitted, provided the original author(s) or licensor are credited and that the original publication in this journal is cited, in accordance with accepted academic practice. No use, distribution or reproduction is permitted which does not comply with these terms.

Вступ. Поліцентризм природознавства вимагає багатомірного бачення наукової картини природи, оскільки на всіх рівнях життя ми ведемо розмову про відкриті системи, кожна 3 яких має функції, які забезпечують іiї зв'язки із більшою системою. Наука в техногенній цивілізації стає одним 3 важливих факторів формування світоглядних установок та цінностей, які визначають відношення людини до світу $[1,2,3,7,8]$. Вона формує картину світу, являє його в якості системи об'єктів, які розвиваються за універсальними законами природи [5]. Ця картина складається на основі досягнень фундаментальних наук. Але оскільки фундаментальні науки постійно виходять за межі звичних уявлень про світ, наукова картина світу може конфронтувати зі звичною свідомістю. Світоглядна функція освіти виходить далеко за межі цивілізаційних надбань в технологіях. Тому й філософсько-методологічне підгрунтя іії повинно стати опорою універсальності світобудови в науковій картині світу, скласти методологічний шлях впровадження нового світобачення людиною дійсності та упорядкувати постулати загальнолюдського поступу в розвитку науки.

Здебільшого інтеграційні процеси розглядаються всередині природничих наук та всередині соціально-гуманітарних. Між двома гілками наукової картини світу - природничонаукової та соціально-гуманітарної такі дослідження є рідкими, але все більше набувають актуальності в наш час. Сьогодні стає питання саме синтетичної картини світу, яка б увібрала 
також і місце технологічної картини світу, що має стати логічним продовженням поєднання природничо-наукової та соціально-гуманітарної гілок, які мають виразити себе в практичному застосуванні тих теоретичних моделей або образних уявлень, які створюються в процесі мисленнєвого моделювання людиною. Причинно-системний підхід дозволяє побачити смисл та причинно-наслідкові зв'язки такого поєднання на прикладі моделі формування універсальної наукової картини світу. Збалансованість процесів диференціації та інтеграції в освіті має досягатися за рахунок онтодидактичного принципу цілісності знань. Але поняття «інтеграція знань» та «міждисциплінарний синтез» на нашу думку не тотожні. Інтеграція знань передбачає проникнення елементів знань між суміжними науками, а міждисциплінарний синтез породжує системне поле мислення, в якому знаходять місце не тільки суміжні науки, але й ті, що не стоять за змістом близько поруч. Таким чином, ми доповнюємо методологічне обгрунтування щодо реалізації міжпредметних зв'язків в природничих науках, що були здійсненні науковцями в даному напрямку, та розширюємо процесуальну частину формування УНКС, формуючи не тільки інтегративне мислення, а новий стиль і спосіб синтетичного мислення людини.

Теоретичне обгрунтування дослідження. Серед різних типів інтеграції змісту освіти виділяють загальнометодологічний тип інтеграції, загальнонауковий та частковонауковий тип. В нашому дослідженні ми враховували загальнометодологічний тип інтеграції та пропонуємо вийти за межі самої інтеграції, щоб побачити повноту поняття цілісності світу.

Для цього означимо, що поняття синтезу охоплює переважну цілісність і бере до уваги побудову цілісності світу і людини в ньому, зокрема об'єднуючи складові світу природи та соціального середовища, в якому проявлена сама людина. Сучасна наука оперує поняттям «загальнонаукова картина світу», розглядаючи ентропійно-синергетичні аспекти природничонаукової освіти та ілюструє єдність природничонаукової картини світу.

Образ світу має бути втіленим через освіту у вихованні вищих ідеалів людини, зокрема розкриваючи суть безперервного розвитку природи: постійна новизна в дослідженні життя; пізнання цінності кожного елементу життя, як і кожної людини, живої істоти; стратегічне моделювання свого розвитку. Методологія природознавства, таким чином, передбачає через природничу освіту передачу образу природи, розширюючи його до образу світу через інтеграцію 3 іншими напрямками науки та виробничої діяльності людини, формує зміст навчання.

Між образом світу та науковою картиною світу у людини є певний динамічний «фільтр», що формується в процесі виховання людини, саме він визначає вмотивовану потребу в навчанні і результат його. Цей «фільтр» і $€$ формоване відношення людини до світу, який має бути суголосний з призначенням людини та їі унікальністю, що розкривається саме в процесі виховання. Отже, формуючи від надсистемної побудови образу світу, зміст навчання проходить через фільтр ставлення людини до цих знань, який формується в процесі виховання в конкретному предметі або дисципліні. Виховуючий вплив навчання стає основою поведінки людини та іï способу життя, хоча часто саме ця ланка залишається досить слабкою, та поінформованість залишає по собі нивілювання загальними принципами життя, що відбивається у викрівлених принципах сучасної людини.

Інтеграція в змісті освіти, таким чином, може відбивати синтетичний рівень думки людства, формуючи універсальну наукову картину світу, якщо універсальний алгоритм всезагальних законів природи відбиватиме єдиний алгоритм поєднання розрізнених спектрів цілісного світу: закон полярності (аналітичні та синтетичні підходи в дисциплінах), закон подоби (повторення фаз аналізу та синтезу в усіх предметних дисциплінах), причинність (результати повторення цих двох фаз в предметних дисциплінах), циклічне накопичення якості результатів, альтернативність вибору циклів зібраних результатів, синхронізація та ієрархічна обумовленість різних циклів дисциплін, перспективи тих аналітично-синтетичних потоків, що сформувалися в результаті інтеграції, що й призводить до результату - синтетичного мислення людини.

Таким чином, в представленій нами моделі універсальної наукової картини світу (УНКС) можливий міждисциплінарний синтез на рівні двох основних напрямків пізнання та предметних областей - природознавства та людинознавства [4].

Образ світу, на основі якого моделюється УНКС в своїй основі має універсальне ядро УНКС. Ядро УНКС, що має складовими основні закони фундаментальних природничих дисциплін, які описують загальну світобудову, розгортається за універсальним алгоритмом всезагальних законів природи на основі принципів моделювання УНКС та проявлені в 
основних трьох станах життя, відтак - функціональних станах систем життя (минулому стані, теперішньому та майбутньому) та формують єдину природопричинність буття, яка розкривається через світоглядні поняття. В оберненому порядку формується процесуальна модель УНКС, відповідно якої відбувається формування УНКС людини та іï наукового світогляду. Так природничо-філософські концепції складають основу системного формування змісту освіти та соціотехнологічної діяльності людини (рис.1).

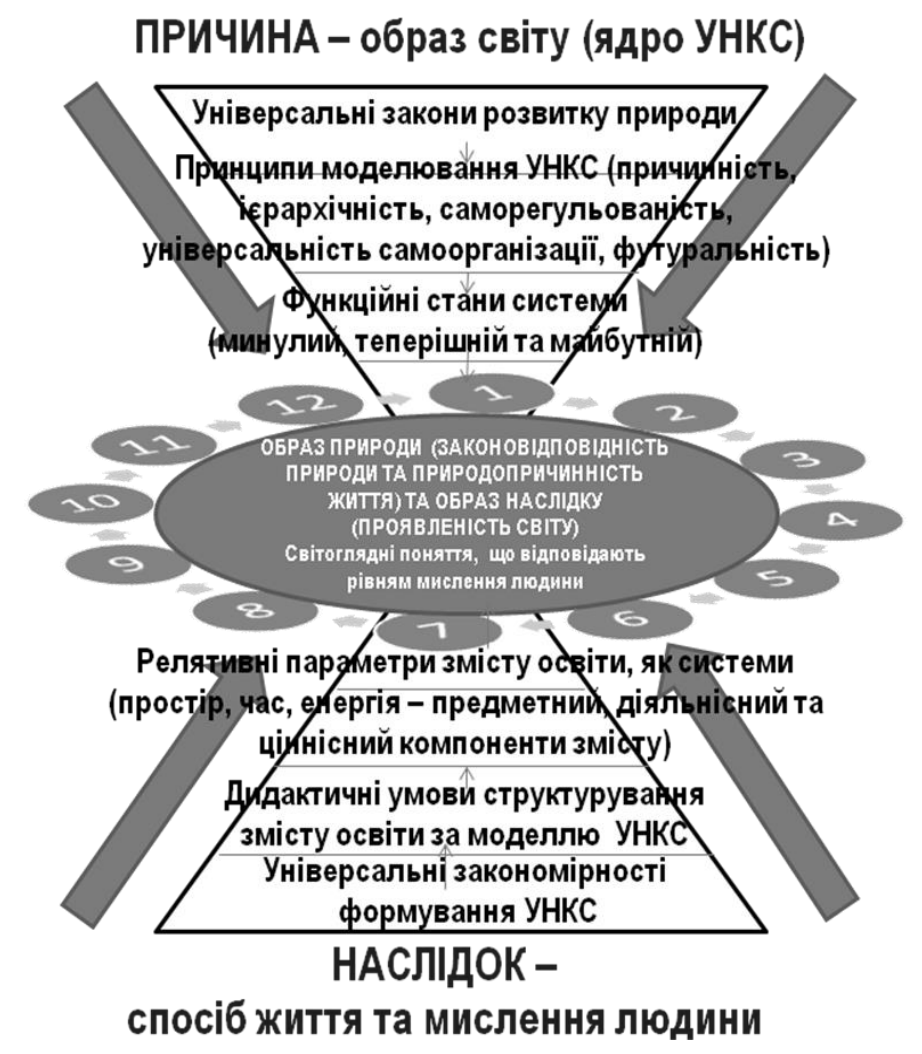

Рис.1. Причинно-наслідкові зв'язки в моделі формування УНКС.

Природопричинність задає параметри наслідковості (образ наслідку - проявленості світу) процесів та явищ через три релятивні параметри (простір, час, енергія), за якими відбувається розвиток будь-якої системи природи, а відтак - й освітньої системи (освітній простір та зміст; процесуальна частина змісту освіти, що реалізується в певному циклі за певний час; та енергія, як отриманий досвід людини в процесі навчання). На основі універсальних закономірностей формування УНКС, які корелюють 3 відповідними дидактичними принципами та напрямками виховання, а також дидактичних умов моделювання змісту освіти за УНКС формується синтетична базова складова світоглядних понять, що відбивають рівень та масштабність мислення людини, складаючи його багато вимірність 3 одного боку, та формує концентрацію на конкретному явищі або процесі. Під універсальними закономірностями формування УНКС на прикладі змісту природничих наук будемо розуміти об'єктивні тенденції формування змісту освіти, що відображаються в універсальному алгоритмі всезагальних законів природи.

Сформулюємо загальні універсальні закономірності, які пропонуємо в обгрунтуванні конструювання змісту освіти відповідно запропонованої моделі УНКС:

- Доцільність (зміст освіти повинен бути спрямованим на здійснення мети педагогічної системи - формування культурно-продуктивної особистості, яка володіє причинно-системним світоглядом). Система має своє призначення, яке зумовлене більшою системою.

- Системність та інтеграиія (зміст освіти має бути екологічним, базуватися на цінності світової культури й універсальні закони розвитку та взаємодії; зміст повинен орієнтувати на побудову внутрішньої системи цінностей, на поєднання й співпрацю зі світом; має включати в себе міжпредметні зв'язки, що сприятиме формуванню системної, цілісної картини світу, розумінню 
місця й ролі людини в ньому як його невід’ємної частини). Система включена в ієрархію більших систем та прагне до узгодження цінностей між особистістю та суспільством.

- Розвиток (зміст повинен враховувати сучасні наукові досягнення, спиратися на універсальні закони розвитку, мотивувати на неперервність росту людини протягом всього життя). Система знаходиться у постійному русі, зміні та розвитку.

- Edність (зміст повинен передбачати єдність теорії та практики, навчання та праці, що сприяє як інтелектуальному, так і духовно-моральному розвитку; формування людинигромадянина, інтегрованого у суспільство й націленого на його розвиток, вдосконалення). Система цілісна та взаємозв'язана з усіма елементами більшої системи.

- Багатоманіття (зміст повинен сприяти різносторонній професійній орієнтації тих, хто навчається, сприятиме формуванню унікальності та неповторності кожного майбутнього фахівця).

- Взаємопов'язаність (зміст освіти повинен передбачати розвиток емоційно-чуттєвої й мотиваційної сфери, викликати емоційний резонанс). Система являє собою сукупність багаторівневих зв'язків, що відбуваються відносно одночасно.

- Універсальність системоутворення (зміст освіти повинен відповідати віковим можливостям тих, хто навчається, бути природовідповідним й здоров'яутворюючим). Система формується взаємодіє та розвивається за універсальними законами.

Загальноприродничий компонент забезпечує формування в студентів природничих спеціальностей основи цілісного уявлення про природу і місце людини в ній. Біологічний компонент забезпечує засвоєння учнями знань про закономірності функціонування живих систем, ï розвиток і взаємодію, взаємозв'язок із неживою природою, оволодіння основними методами пізнання живої природи, розуміння біологічної картини світу, цінності таких категорій, як знання, життя, природа, здоров’я, формування свідомого ставлення до екологічних проблем, усвідомлення біосферної етики, застосування знань 3 природознавства у повсякденному житті та майбутній професійній діяльності, оцінювання їх ролі для суспільного розвитку, перспектив розвитку біології як науки та ії значення у забезпеченні існування біосфери.

Матеріали та методи. Нами була запропонована модель формування УНКС, експертиза основних положень якої проводилась в грудні 2016 року на кафедрі загальної біології, кафедрі екології та охорони природи та кафедрі хімії Чернігівського національного педагогічного університету імені Т.Г.Шевченка, в квітні-травні 2017 року на кафедрі загальної біології та методики навчання природничих дисциплін Тернопільського національного педагогічного університету імені Володимира Гнатюка. В 2018-19н.р. нами був сформований та апробований експериментальний курс для студентів магістратури педагогічних закладів вищої освіти (ЗВО) «Універсальна наукова картина світу: методологія природознавства». Незалежно один від одного експерти визначали «вагомість» кожного положення за 10-бальною шкалою, визначаючи рівень відповідності його висунутим вимогам.

Спеціалістам повідомлялася мета експерименту, правила його проведення, кожен отримував від автора інформацію про основні положення УНКС, принципи побудови запропонованої моделі. Заповнені анкеті вивчалися та аналізувалися. Відповіді оцінювалися якісно та кількісно, опрацьовувалися методами математичної статистики, розглядаючи показники кореляції виставлених оцінок до відповідних вимог щодо «вагомості» положень [6].

На експертизу подавалися такі положення УНКС (у відповідності з методологічною віссю провідних ідей УНКС у змісті освіти), що лежать в основі формування світоглядної цілісності знань студентів педагогічних ЗВО:

1. Сдність Всесвіту обумовлює цілісність природи в трьох параметрах: просторовому (матеріальному), часовому, енергетичному. Цілеорієнтованість (телеологічність) наукової картини світу є основою для цілепокладання в обгрунтуванні спрямування розвитку життя та еволюції форм його.

2. Природа, як система, в основі своїй має ієрархію рівнів організації матерії в їх системній супорядності та різнорівневого узгодження відповідно функційним характеристикам кожної з підсистем. Кожний наступний рівень інтегрує в собі всі попередні рівні організації, що проявлене в універсальному алгоритмі всезагальних законів природи (полярності, наступності, причинності, циклічності, альтернативності, ієрархічності, цілеорієнтованості).

3. Узгоджений взаємообумовлений розвиток та вдосконалення систем життя, передбачає альтернативність вибору системою шляхів розвитку. Самоорганізація систем життя 
обумовлює їх ступінь свободи у виборі на основі загальних (емерджентних) властивостей надсистеми, що зумовлюють нову якість їі.

4. Динаміка форм руху матерії забезпечується циклічністю процесів та неперервним ïх ритмом. Флуктуації в системі призводять до виходу системи життя на новий якісний рівень розвитку.

5. Стійкість та адаптація природних систем зумовлена універсальним характером адаптогенеза в певних умовах середовища існування життя.

6. Нескінченність процесів та їх результативність обумовлюється причиннонаслідковими зв'язками в природних системах, що породжує резонансні явища між різними формами життя та рівні фізичних, хімічних та біологічних взаємодій.

7. Різноманітність форм життя та види їх взасмодій існують в суцільній цілісності світу та залежать від рівня організації матерії, на якому розглядається взаємозв'язок різних форм матерії.

8. Самопідтримання (саморегуляція) системою своєї життєдіяльності обумовлюється iï дуальністю, що закладає iї гомеостаз.

Результати та їх обговорення. Незалежно один від одного експерти визначали ранги поданих на експертизу положень за кожним критерієм: можливість розкриття основних положень УНКС на основі існуючого змісту освіти педагогічних ЗВО; значимість для здійснення міждисциплінарної інтеграції наук; можливість розкриття системності побудови світу; дидактична відповідність принципам; ступінь зв'язку із практичними сферами життя людини.

Таким чином, кожен із запропонованих інтегральних показників «дидактичної якості», дозволив здійснити об'єктивну оцінку винесених на експертизу положень УНКС. Кожна 3 вимог дидактичної якості оцінювалась на 7-ми рівнях системоутворення запропонованої моделі за 10-бальною шкалою у відповідності до кожного з положень.

Можливості розкриття основних положень УНКС на основі існуючого змісту освіти вказують на високий аксіологічний потенціал та високий показник загальнотеоретичного тлумачення основних понять та процесів.

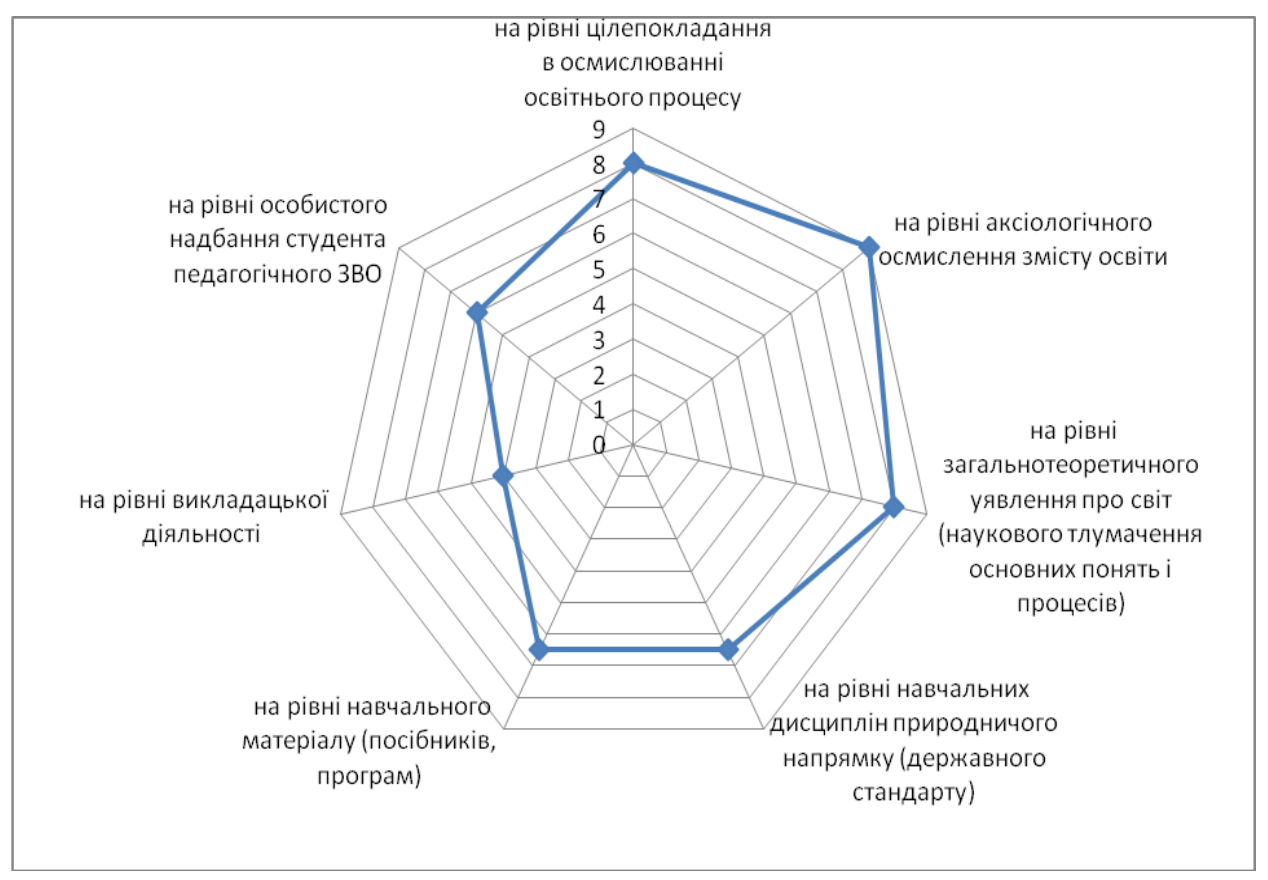

Рис. 2. Результати експертного оцінювання положень УНКС за критерієм можливості розкриття основних положень УНКС на основі існуючого змісту освіти педагогічних $3 В О$.

Невисокі показники в оцінці експертів на рівні викладацької діяльності свідчить про нагальну необхідність підготовки викладацького складу до рівня синтетичного мислення в міждисциплінарній сфері природознавства (рис2). 


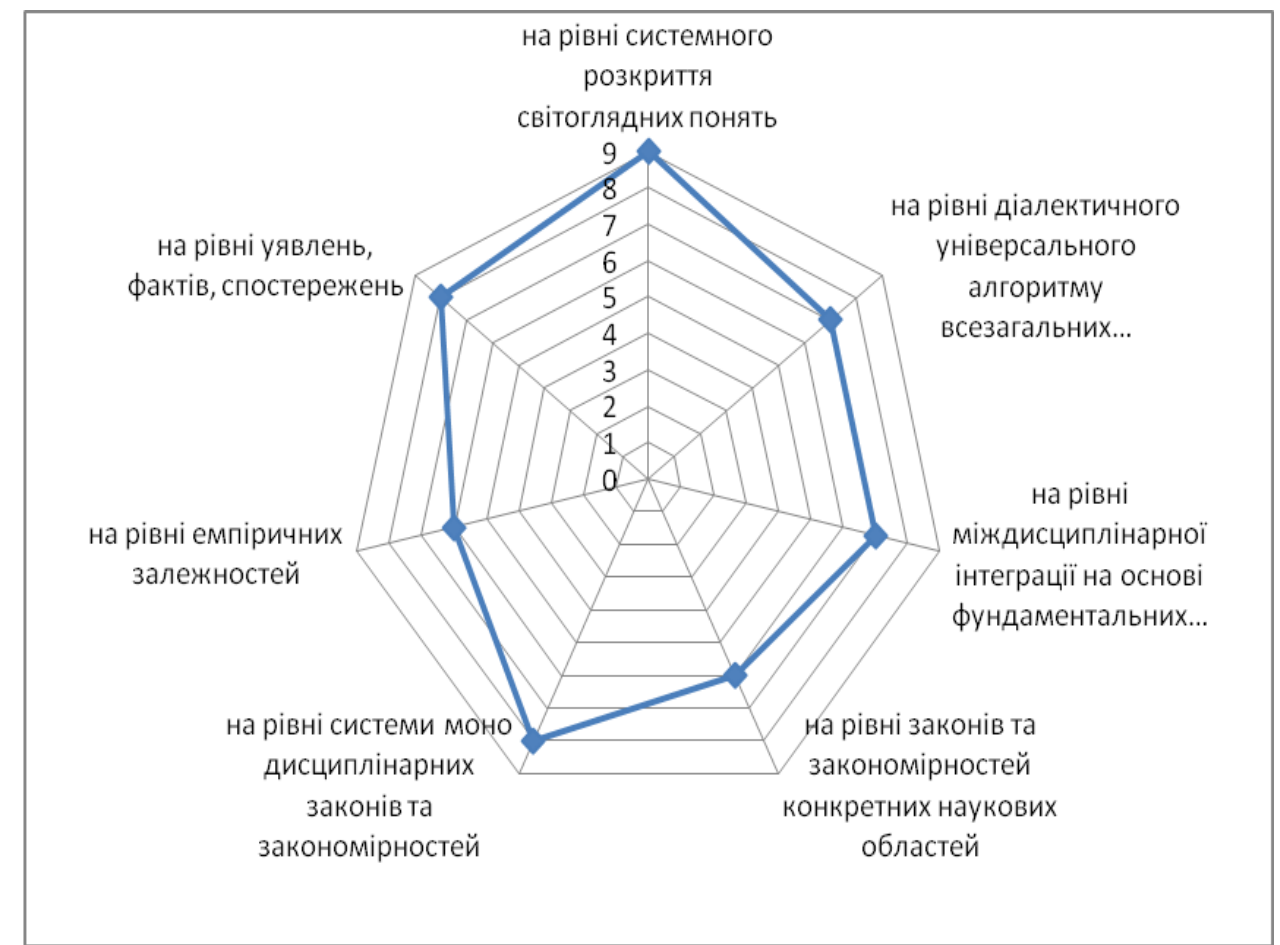

Рис. 3. Результати експертного оцінювання положень УНКС за критерієм значимості для здійснення міждисииплінарної інтегращії наук.

Значимість для здійснення міждисциплінарної інтеграції наук потенціал запропонованої моделі формування УНКС високо оцінюється на рівні системного розкриття світоглядних понять, а також уявлень, фактів та спостережень природи (рис.3).

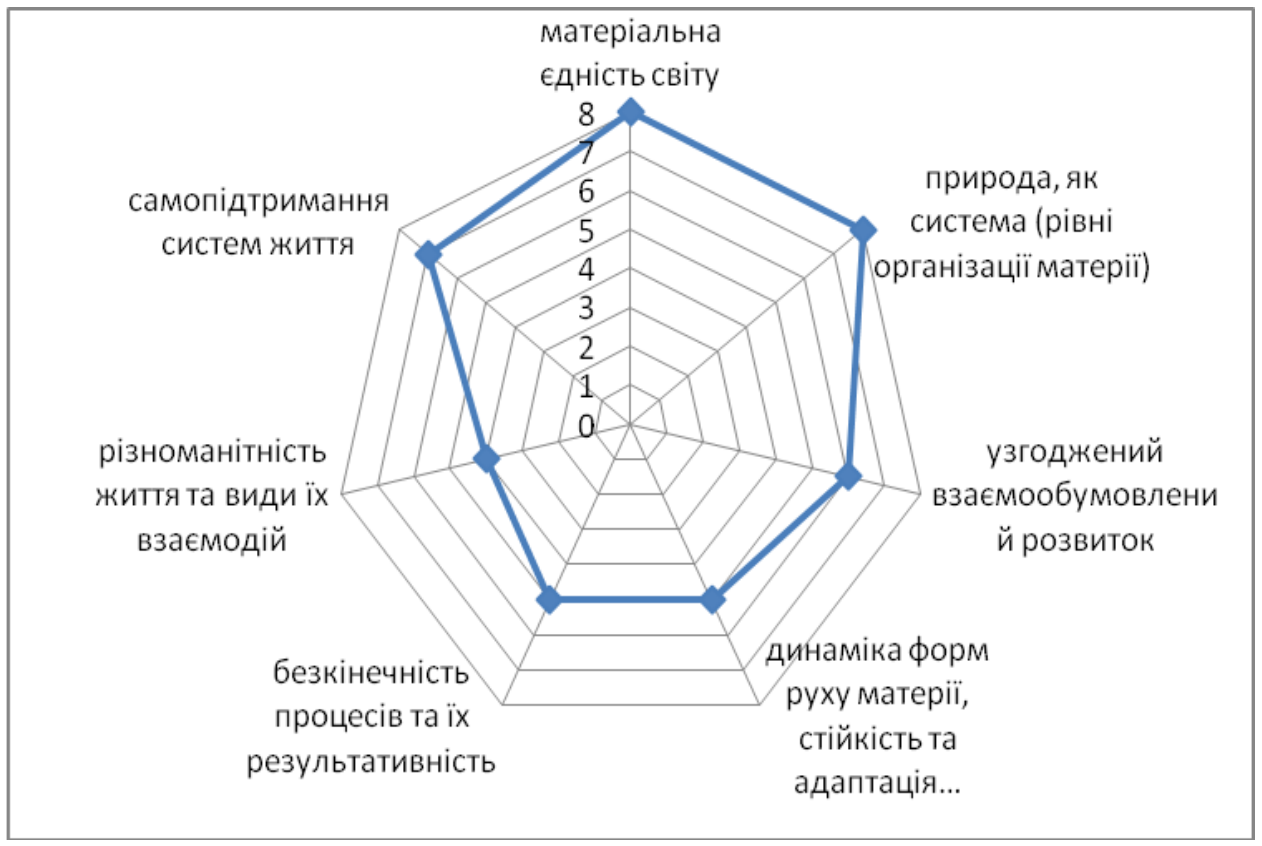

Рис. 4. Результати експертного оцінювання положень УНКС за критерієм можливості розкриття системності побудови світу (у відповідності до провідних ідей природничої освіти).

У відповідності до провідних ідей природничої освіти [9] оцінка експертів вказала на високе положення пропонованої моделі щодо розкриття матеріальної цілісності та єдності природи, природи, як системи (рис.4). Нижчі показники щодо інших критеріальних означень свідчить про те, що необхідним $\epsilon$ методична та дидактична розробка необхідних супровідних матеріалів до пропонованих експериментальних підходів для впровадження їх в освітній процес. 


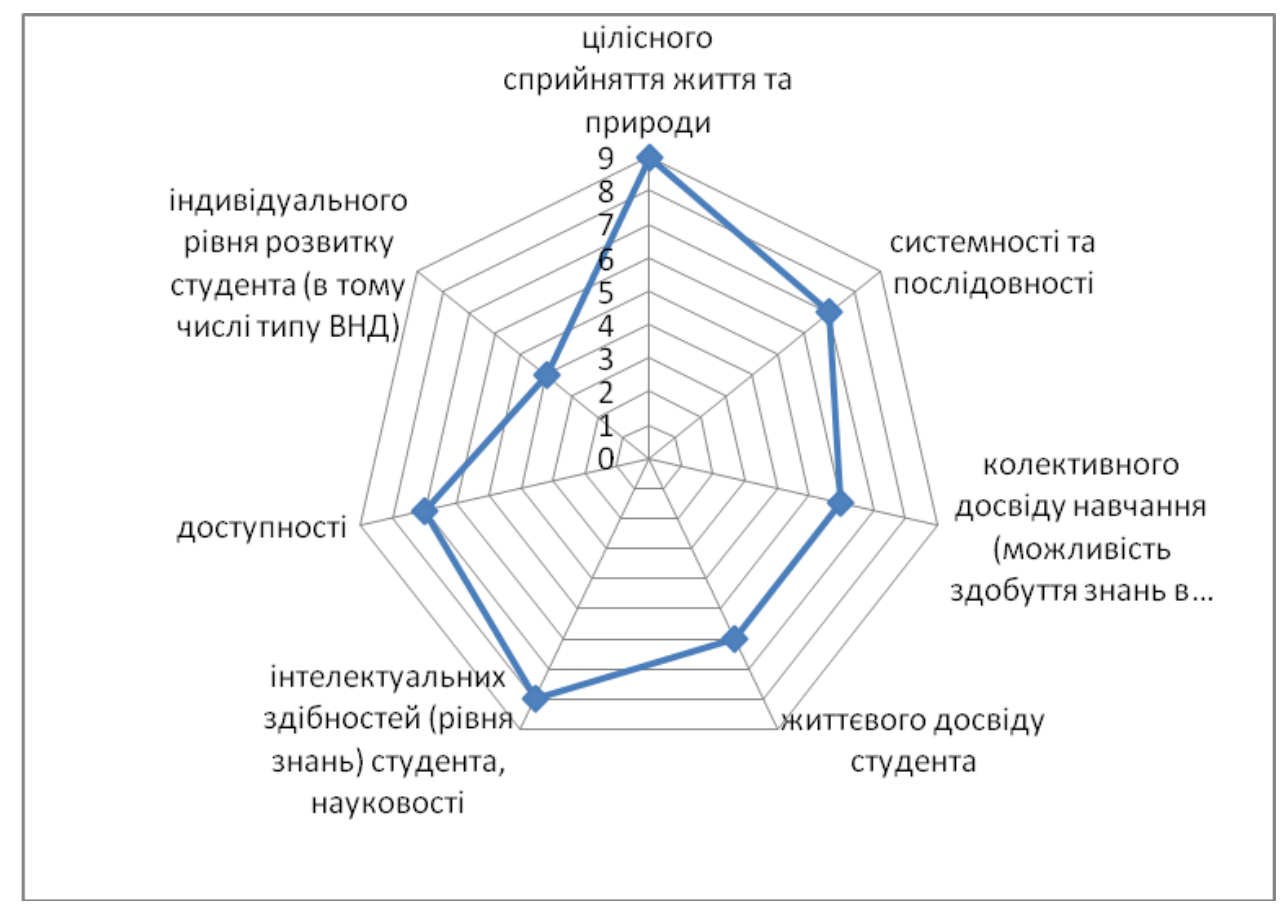

Рис. 5. Результати експертного оцінювання положень УНКС за критерієм дидактичної відповідності принципам.

Дидактична відповідність принципам в першу чергу визначає високий показник щодо розкриття цілісного сприйняття життя та природи (рис.5). Потужний потенціал вбачається також в розвитку інтелектуальних (ментальних) здібностях студента.

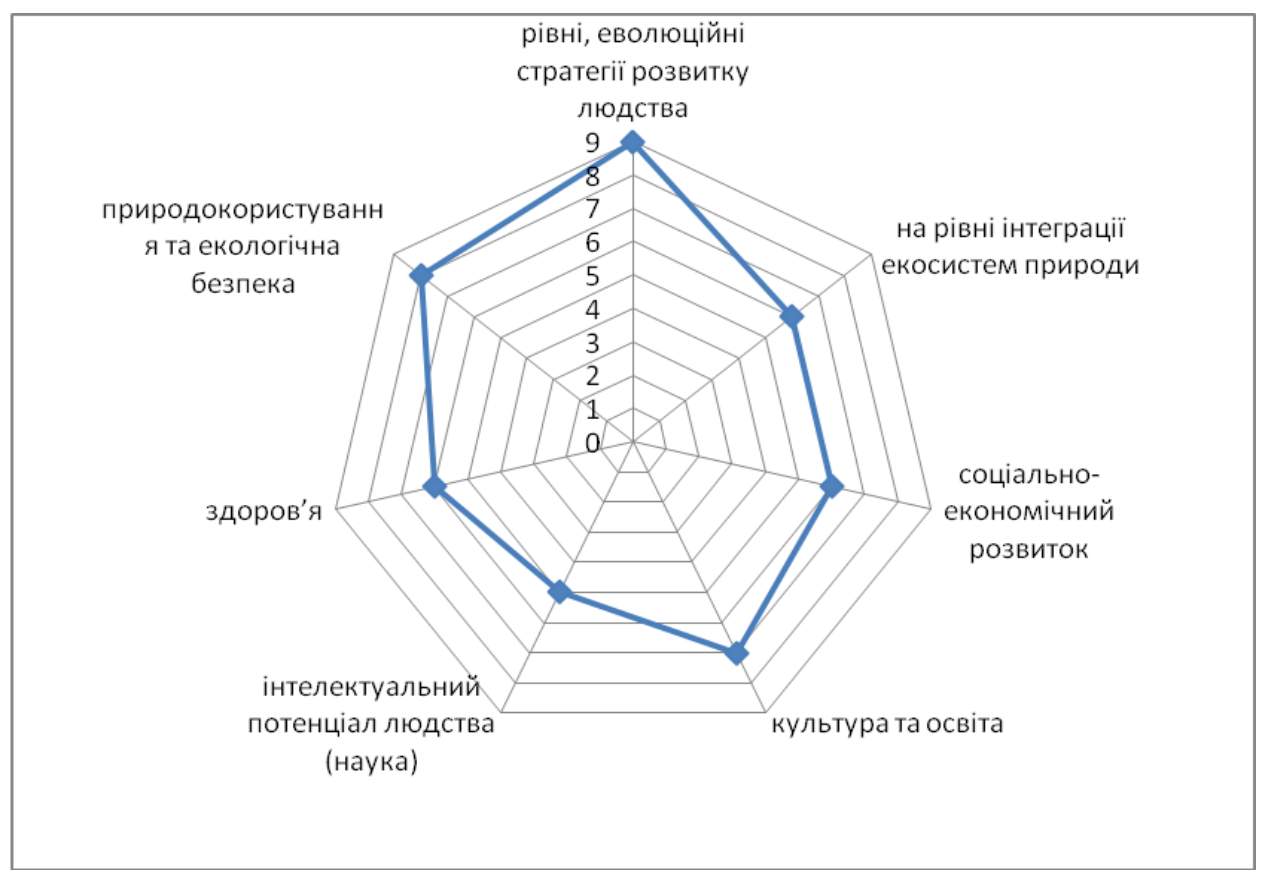

Рис. 6. Результати експертного оцінювання положень УНКС за критерієм зв 'язку із практичними сферами життя людини.

Також експертне оцінювання виявило значний потенціал запропонованого підходу в практичних сферах життя за показниками еволюційної стратегії людства, природокористування, культури та освіти (рис.6).

Завданням наступного етапу експериментального дослідження стало виявлення ступеня формування світоглядних понять, що лежать в основі наукових ідей УНКС, що мали відображатися в змісті експериментальних курсів. 
Для участі в експерименті було обрано 31 студент магістратури безпосередньо в групі 3 експериментального курсу «Універсальна наукова картина світу: методологія природознавства» в двох потоках (березень-квітень 2018p., вересень-грудень 2019p.). Ми визначили достатню кількість учасників експерименту, керуючись поняттям «малої вибірки», яку можна використати в дидактичному експерименті. За вимогами «малої вибірки» для порівняння результатів достатньо мати в експериментальній групі 24 реципієнти, оскільки відповідно до твердження математичної статистики, дані, що зіставляються після цього числа, починають повторюватися. Отже, в аналізі результатів ми доходимо висновків, справедливих для всієї практики в цілому. Контрольні групи вважаємо недоцільними, оскільки в них не відбувалося б цілестрямованого розкриття основних положень УНКС за пропонованою моделлю, і наслідки роботи були б вищими в порівнянні з експериментальною.

Формувальному експерименту передував підготовчий етап. Його мета полягала в розробці навчальної програми та робочої програми з експериментального курсу, допоміжних дидактичних матеріалів для студентів магістратури (презентаційні матеріали, відео супровід, додаткові текстові матеріали, електронні та друковані шаблони для заповнення під час вправ на опанування практикою моделювання), який би сприяв розкриттю суті виділених методологічних основ УНКС та основних іiі положень. Для цієї мети були проведені ряд локальних експериментів (окремі концептуальні теми, що складають основу пропонованої моделі УНКС та практико орієнтовані теми з моделювання), щодо втілення основних ідей запропонованої моделі формування УНКС в змісті навчальних дисциплін «Методика навчання біології», «Методика навчання біології у старшій школі», «Сучасні педагогічні технології на уроках біології», «Новітні технології екологічного виховання учнів» для студентів бакалаврів; «Методика навчання біології у вищій школі», «Соціоекологія» для студентів магістратури різних років навчання (2017-2018н.р., 2018-2019н.р., 2019-2020н.р.). Всього до локальних експериментів було задіяно 53 студента експериментальних груп та 49 студентів контрольних груп. Були також розроблені та апробовані практикоорієнтовані тренінги щодо опанування студентами моделей формування УНКС та практики моделювання - «Освітні системи. Теорія та практика їх моделювання», «Універсалії світобудови».

У результаті локальних експериментів підготовчого етапу та експериментального дослідження, мета якого полягала у виявленні рівня доступності означених теоретичних положень УНКС майбутнім вчителям природничих наук, вияснилось, що відібрана інформація, на основі якої розкривались основні положення УНКС в основному доступна для студентів IIIV (VI) курсів, вони швидко набувають навички моделювання за пропонованим причинносистемним підходом. Проте, спостерігались деякі труднощі у сприйнятті понять світоглядного рівня, які ілюструють системність побудови наукової картини світу взагалом, певні питання широкого узагальнення понять, законів, принципів окремих дисциплін в єдиному міждисциплінарному синтезі. Була виявлена потреба у додаткових знаннях суміжних природничих дисциплін. Саме тому до експериментальної групи лабораторного експерименту ми запросили студентів магістратури, які навчаються за різним природничим спрямуванням, що дало можливість продуктивного «перехресного» обговорення поставлених практичних завдань, вправ, та створення творчої атмосфери пошуку та взаємонавчання. Практика застосування універсального алгоритму всезагальних законів природи, які узагальнюють всі відомі в сучасній науці підходи та напрямки дослідницького пошуку, вимагала ретельно підібраних практичних вправ щодо застосування запропонованого алгоритму на конкретних прикладах явищ чи процесів природи. Цьому сприяла підібрана методика розгляду світоглядних понять за їх схожістю та відмінністю, що стало також в основу діагностування й рівня теоретичного мислення студентів. В ряді локальних експериментів ми мали як контрольні, так і експериментальні групи, тому могли порівнювати динаміку зміни рівня теоретичного мислення студентів, що відбивала оперування поняттями світоглядного рівня в якісному та кількісному вимірі. Результати дали можливість скоректувати набори понять, що подавалися для порівняння під час лабораторного експерименту.

Висновки. Природничо-наукове мислення майбутнього вчителя відповідає синтетичному мисленню, відрізняється багатоваріантністю та системністю. Процес виховання в освітньому процесі виступає своєрідним динамічним «фільтром» ставлення до набутих знань, який визначає вмотивовану потребу в навчанні та його світоглядний результат. Виділені 
універсальні закономірності формування УНКС, що корелюють 3 основними дидактичними принципами та напрямками виховання, а також дидактичними умовами моделювання змісту освіти за УНКС. Представлений універсально-діалектичний алгоритм розвитку світоглядних понять відповідає універсальному алгоритму всезагальних законів природи. Ієрархічний взаємозв'язок у моделі формування УНКС розглядається через різні рівні світоглядного світосприйняття в різнорівневому причинно-наслідковому зв'язку, враховуються п'ять рівнів змісту освіти та пропонуються два синтетичних рівня відповідно причинно-системного підходу - рівень аксіологічного осмислення концепцій змісту освіти та рівень телеологічного осмислення спрямованості освіти. Світоглядні поняття, визначені в процесі аналізу змісту сучасних програм шкільної біологічної освіти, зокрема експериментальних інтегрованих курсів «Природничі науки» та сучасних підручників для студентів ВЗО, що освітлюють сучасні концепції природознавства, дозволили виділити єдину методологічну вісь, яка підтримує провідні ідеї сучасної природничо-наукової картини світу.

\section{REFERENCES}

1. Bordonskaja L.A., Serebrjakova S.E., Starostina S.E. (2010). Koncepcii sovremennogo estestvoznanija v voprosah i otvetah: uchebnoe posobie [Concepts of modern natural science in questions and answers: a manual]. Chita Zabajkal. gos. gum.-ped. un-t Publ.

2. Dyshlevij P.I., Jacenko L.V. (1984). Chto takoe obshhaja kartina mira [What is a general worldview]. M.: Znanie.

3. Il'chenko V.R. (1993). Formirovanie estestvennonauchnogo miroponimanija shkol'nikov [Developing schoolchildren's natural-scientific world outlook]. Moscow, Prosveshhenie Publ.

4. Kolesnik M.O., Poljakov V.A. (2019), «Modeljuvannja naukovoï kartini svitu na osnovi universal'nogo algoritmu vsezagal'nih zakoniv prirodi» [Modeling a Scientific Worldview on the Premises of Universal Laws of nature]. Vseukraïns'kij naukovo-praktichnij zhurnal «Direktor shkoli, liceju, gimniziï» - Special'nij tematichnij vipusk «Vishha osvita Ukraïni u konteksti integraciï do evropejs'kogo osvitn'ogo prostoru». №4. Vol. III (85). Kiyv, Gnozis. 405-422.

5. Leont'ev A.N. (1979). Psihologija obraza [Psychology of the image]. Vestn.MGU. Ser.14. Psihologija,. №2. 3-13.

6. Pidlasij I.P. (1998). Diagnostika ta ekspertiza pedagogichnih proektiv [Diagnostics and expertise of pedagogical projects]. Kiyv, Ukraïna.

7. Romanov Ju.I. (2014). Sovremennaja nauchnaja kartina mira: uchebnik dlja studentov [Modern scientific worldview: a textbook for students]. Gatchina : Izd-vo GIJeFPT Publ..

8. Rybalov L.B., Sadohin A.P. (2010). Koncepcii sovremennogo estestvoznanija: uchebnoe posobie dlja studentov vysshih uchebnyh zavedenij, obuchajushhihsja po social'no-gumanitarnym special'nostjam [Concepts of modern natural science: a textbook for students majoring in social sciences and humanities]. Moscow, JuNITI-DANA Publ.

9. Stepanyuk A., Grubinko V., Kolesny`k M. (2019), «Innovacijni pidxody` do formuvannya zmistu pry`rodny'choyi osvity' shkolyariv» [Innovative approaches towards modeling the content of schoolchildren's natural education]. Osvita XXI stolittya: teoriya, prakty`ka, perspekty`vy`, materialy` Pershoyi mizhnarodnoyi naukovo-prakty'chnoyi Internet-konferenciyi [Education 21 AD: theory, practice and perspectives]. Kyiv [in Ukrainian]. 